\title{
2005-06 Farm Bill Survey: Florida Producer Views on Farm Programs and Budget Priorities, Commodity Programs and Risk Management Policy ${ }^{1}$
}

Rodney L. Clouser²

\section{Introduction}

This is the fourth fact sheet in a series of four which describes the attitudes and opinions of Florida farm producers toward legislation that may be considered as the U.S. Congress debates the next farm bill. Florida was one of 27 states that participated in a national farm producer survey. The survey was completed in the winter of 2005-06, and the data reported are based on 244 valid and usable surveys that were returned.

Florida farm producers have participated in similar surveys just prior to enactment of each new farm bill legislation since 1985 . Of the 27 states participating in the current survey, five were from the South: Alabama, Florida, Georgia, North Carolina, and Texas. Nationally, southern states accounted for about 30 percent of all farms included in the statistical analysis. In total, the southern and north central regions accounted for 76 percent of farms used for statistical analysis.

This fact sheet focuses on questions of farm programs, budget priorities, and commodity and risk management programs. Various socioeconomic characteristics of those responding to the survey were reported in fact sheet FE663. Opinions on rural development; open space and farmland preservation; labor; research funding allocation; and inclusion of fruits, vegetables, and specialty crops in federal government commodity programs were reported in fact sheet FE664. Florida producer attitudes on conservation and environmental policy, trade policy, food system, and regulatory policy were reported in fact sheet FE665.

\section{Farm Bill Goals}

Producers were asked to rate the importance of eight Farm Bill goals on a five-point scale, where $1=$ least important and $5=$ most important. The results are presented in Figure 1. The highest-ranked goals for Florida producers were assurance of a safe, secure, abundant, and affordable food supply (4.4) and enhancing opportunities for small beginning farms/ranches (4.3). Two other goals closely followed the top two ranked goals: increasing the competitiveness of U.S. agriculture in global markets (4.1) and reducing the nation's dependency on

1. This is EDIS document FE666, a publication of the Food and Resource Economics Department, Florida Cooperative Extension Service, Institute of Food and Agricultural Sciences, University of Florida, Gainesville, FL. Published December 2006. Please visit the EDIS website at http://edis.ifas.ufl.edu.

2. Rodney L. Clouser, Professor, Food and Resource Economics Department, Florida Cooperative Extension Service, Institute of Food and Agricultural Sciences, University of Florida, Gainesville, FL.

The Institute of Food and Agricultural Sciences (IFAS) is an Equal Opportunity Institution authorized to provide research, educational information and other services only to individuals and institutions that function with non-discrimination with respect to race, creed, color, religion, age, disability, sex, sexual orientation, marital status, national origin, political opinions or affiliations. U.S. Department of Agriculture, Cooperative Extension Service, University of Florida, IFAS, Florida A. \& M. University Cooperative Extension Program, and Boards of County Commissioners Cooperating. Larry Arrington, Dean 
non-renewable sources of energy (4.1). The remaining four goals were ranked as follows: protecting the country's land, water, and environmental resources (3.9); enhancing farm income (3.8); enhancing rural economies (3.7); and reducing price/income risk (3.5). Rapidly increasing prices for oil and increased costs to produce agricultural commodities resulting from oil price increases have most likely increased the importance of renewable energy sources to Florida farm producers.

\section{Program Funding}

Producers were asked ten questions regarding the maintenance of funding for current programs (Figure 2). If funding for future programs were reduced or if funding needed to be reallocated among the various programs, then it is important for producers to prioritize what programs are most important. Using the same five-point scale ( $1=$ least important and $5=$ most important), Florida producers ranked one program significantly higher than all others, and that was disaster assistance programs (4.2). Recent disease problems among crops produced in the state, coupled with significant damage from two back-to-back years of hurricanes, may help to explain this result. Five programs ranked between 3.2 and 3.7 on the five-point scale. Crop and livestock insurance programs (3.7), typically authorized external to traditional farm bill legislation, and preservation programs (3.7), such as the Farm and Ranch Land Preservation and Grassland Reserve Program, tied for the next most important programs in terms of maintaining funding. These programs were closely followed by agricultural credit programs, such as direct and guaranteed loans (3.6); working land conservation programs, such as Environmental Quality Incentive Program and the Conservation Security Program (3.4); and land retirement programs, such as the Conservation Reserve and Wetland Reserve Program (3.2). Four current programs were ranked low in terms of priorities: fixed, decoupled crop commodity payments or direct payments (2.7); crop commodity payments tied to price or counter-cyclical payments (2.6); crop commodity payments tied to price and production, such as commodity loans and loan deficiency payments (2.7); and livestock commodity support programs (2.6).

Because of newly emerging issues and tradeoffs that typically occur at budget time, producers were asked to rank the importance of seven additional topics in terms of new or reallocated funding. These rankings are presented in Figure 3. All program areas had scores that ranged between 3.1 and 3.8. Florida producers ranked food safety programs highest (3.8), while support programs tied to farm income (3.1) and support for non-program commodities such as fruits and vegetables (3.1) ranked lowest.

\section{Commodity and Risk Management Programs}

Several questions were asked concerning phasing out commodity payments, reducing commodity payments, targeting commodity payments, or lowering commodity payments through alternative methods. Results are presented in Table 1 . Florida producers slightly prefer phasing out commodity payments completely over the next farm bill (35.2 percent agree or strongly agree) to not phasing out commodity payments (26.2 percent disagree or strongly disagree). However, a higher percentage disagrees with reducing payments (29.8 percent) than agrees with the concept of reducing payments (25.4 percent). A majority of Florida producers agree or strongly agree (56.1 percent) that commodity payments should be targeted specifically to small farms. This might have been expected since over 52 percent of respondents indicated that a "small farm" had less than $\$ 100,000$ in annual sales, and 74 percent of those responding to the survey had farm sales less than $\$ 100,000$.

Alternative methods to reduce farm commodity payments were weakly supported by Florida producers, with between 26.6 percent and 37.7 percent agreeing or strongly agreeing with the concept. Over 34 percent of producers favored reducing payment amounts, 37.7 percent favored eliminating the "three-entity rule", and 26.6 percent favored eliminating unlimited use of commodity certificates and crop forfeitures. A large number of producers answered they "didn't know" concerning their preferences on the latter two options. This may 
indicate a lack of understanding on these issues. The three-entity rule allows producers to receive payments on up to three different farm entities, which allows payment limits for the individual to be doubled. The forfeiture of grains in lieu of repayment of loans is not currently counted as part of the payment limitation.

\section{Buy-out Programs}

Producers were asked questions regarding a commodity buy-out program. Although there is nothing specifically on the agenda regarding this issue, buy-out programs have been used as a policy tool recently for tobacco and peanuts. In Florida, just fewer than 26 percent (Table 2) of those surveyed supported the concept of a commodity buy-out program, over 33 percent indicated they did not support a buy-out program, and 37 percent indicated they didn't know or had no opinion on this policy option. Those who supported a 15-year buy-out with a lump sum payment (24.2 percent) were equally split with those who didn't favor this option (24.2 percent), but 45 percent indicated they didn't know or had no opinion on this option. Results were similar on a 15-year buy-out but with annual installment payments (yes: 22.5 percent, no: 23.4 percent, don't know or no opinion: 46.7 percent). Slightly more producers (approximately 25 percent) were receptive to a 25-year buy-out, compared to the 15-year program with either a lump sum or annual installment payments. Still, over 46 percent didn't know or had no opinion on these latter options.

\section{Summary}

Florida producers' highest ranked goals for a new Farm Bill were assurance of a safe, secure, abundant, and affordable food supply (4.4), and enhancing opportunities for small beginning farms/ranches (4.3). In terms of funding for existing programs, Florida producers ranked one program significantly higher than all others, and that was disaster assistance programs (4.2). In terms of new or reallocated funding for programs, Florida producers ranked food safety programs highest (3.8). A majority of Florida producers agree or strongly agree (56.1 percent) that commodity payment should be targeted specifically to small farms. Only a relatively small number of Florida producers (25.8 percent) supported the policy option of a commodity buy-out program.

\section{References}

Clouser, R.L. 2006. 2005-06 Farm Bill Survey: Characteristics of Florida Producers Who Participated. Electronic Data Information Source (EDIS) FE663. Food and Resource Economics Department, University of Florida, Gainesville, FL. http://edis.ifas.ufl.edu/FE663.

Clouser, R.L. 2006. 2005-06 Farm Bill Survey: Florida Producer Views on Rural Development, Open Space and Farmland Preservation, Labor, Research Funding Allocation and Inclusion of Fruits, Vegetables and Specialty Crops in Federal Government Commodity Programs. Electronic Data Information Source (EDIS) FE664. Food and Resource Economics Department, University of Florida, Gainesville, FL. http://edis.ifas.ufl.edu/FE664.

Clouser, R.L. 2006. 2005-06 Farm Bill Survey: Florida Producer Views on Conservation and Environmental, Trade, Food System and Regulatory Policy. Electronic Data Information Source (EDIS) FE665. Food and Resource Economics Department, University of Florida, Gainesville, FL.

http://edis.ifas.ufl.edu/FE665.

Lubben, B.D., N.L. Bills, J.B. Johnson, and J.L. Novak. 2006. The 2007 Farm Bill: U.S. Producer Preferences for Agricultural, Food, and Public Policy. [National Public Policy Education Committee Publication Number 2006-01]. Oak Brook, IL: Farm Foundation.

Monke, J. 2003. Payment Limits for Farm Commodity Programs: Issues and Proposals. Congressional Research Service, Washington, D.C. 


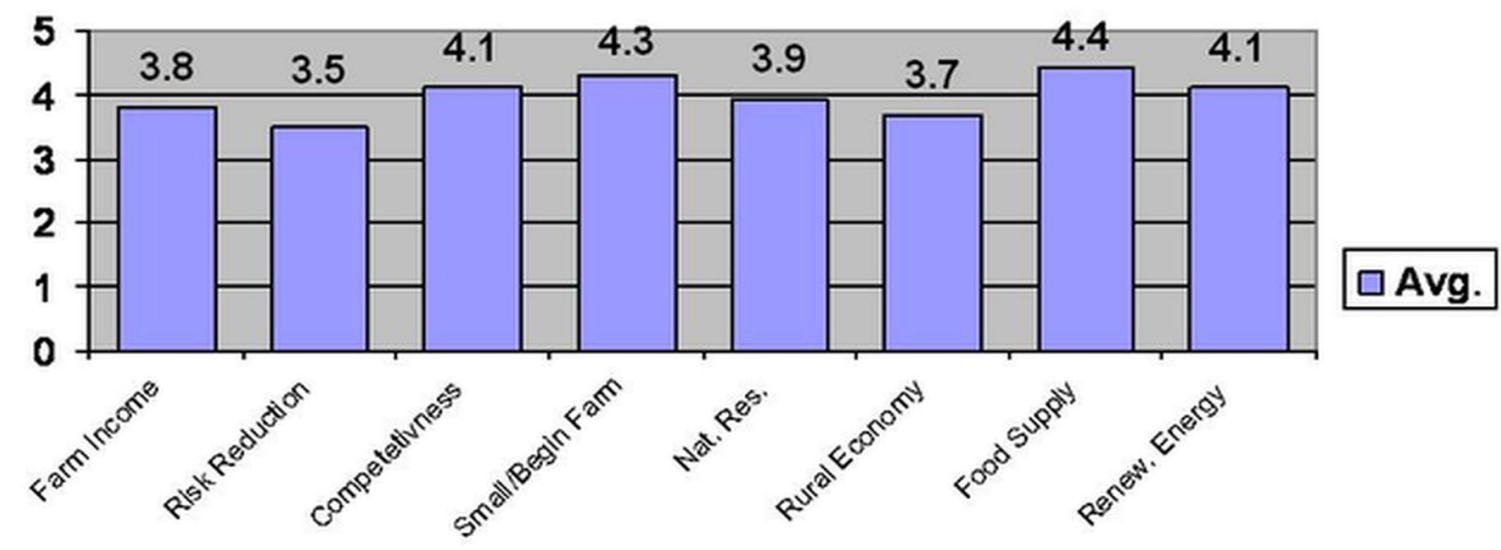

Figure 1. Farm bill goals.

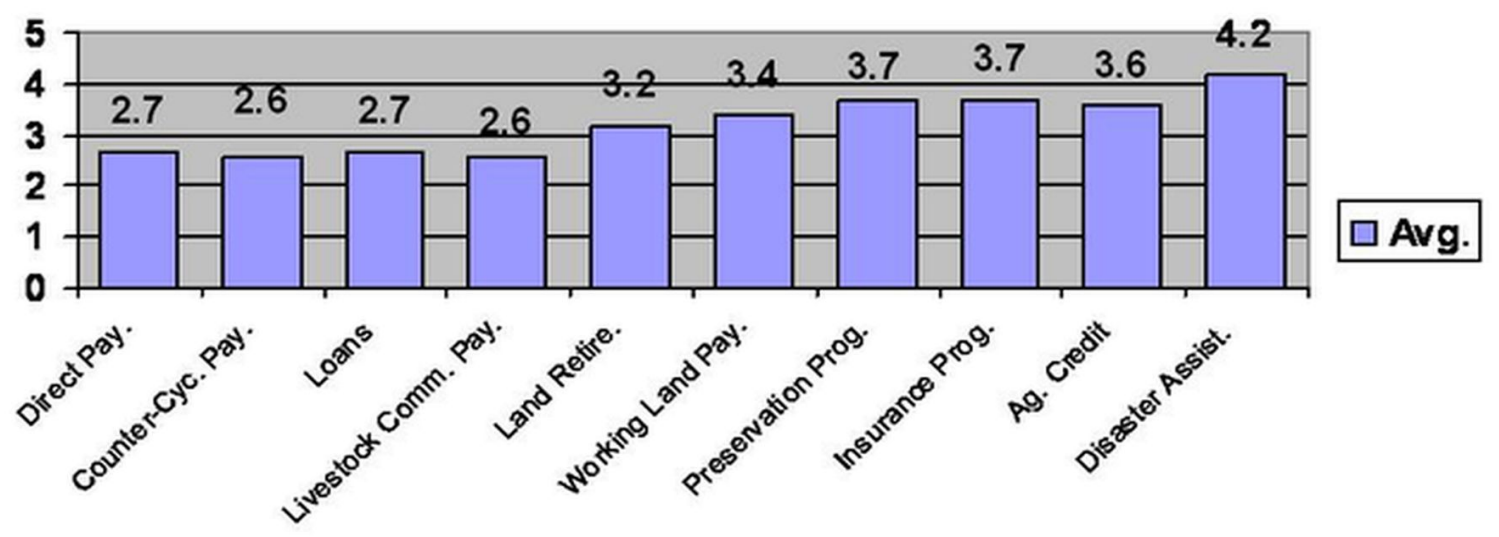

Figure 2. Maintenance of program funding.

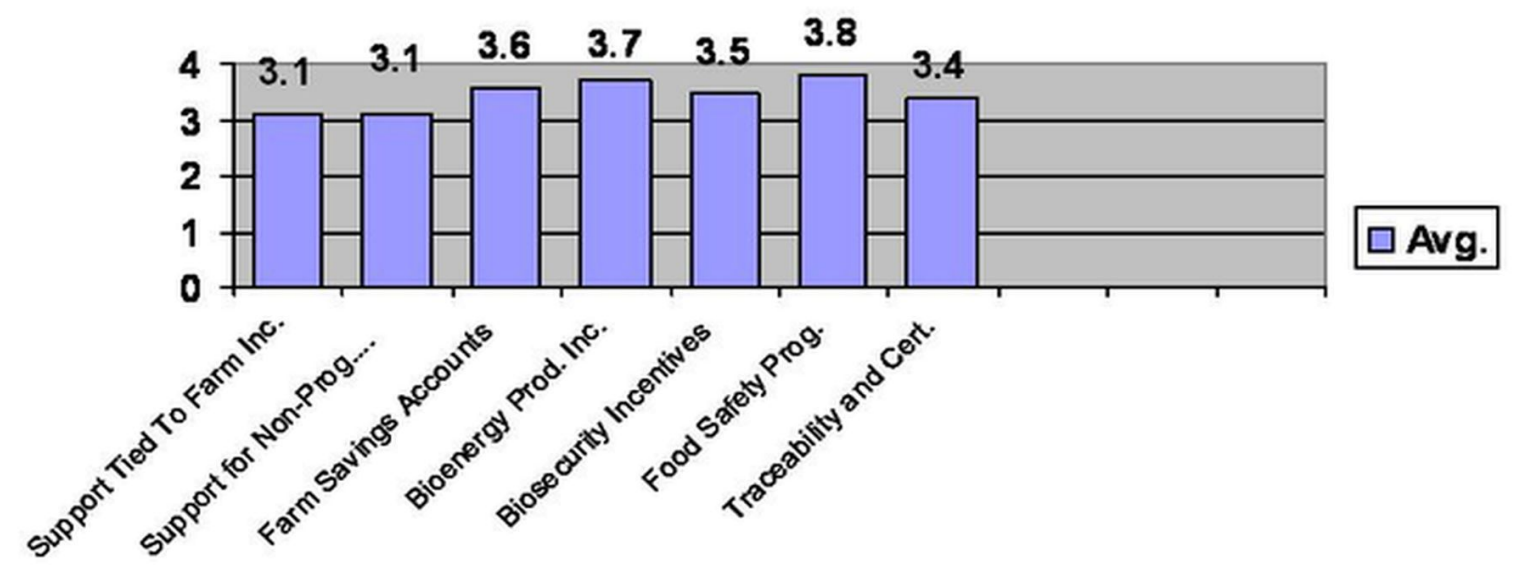

Figure 3. New or reallocated program funding. 
Table 1. Florida producer views on commodity program policies.

\begin{tabular}{|c|c|c|c|c|}
\hline Policy Alternative & $\begin{array}{c}\text { Disagree or } \\
\text { Strongly Disagree }\end{array}$ & Neutral & $\begin{array}{c}\text { Agree or } \\
\text { Strongly Agree }\end{array}$ & Don't Know \\
\hline $\begin{array}{l}\text { Phase out commodity payment over the } \\
\text { length of the } 2007 \text { Farm Bill }\end{array}$ & $26.2 \%$ & $19.3 \%$ & $35.2 \%$ & $14.8 \%$ \\
\hline $\begin{array}{l}\text { Reduce commodity payments in the } \\
2007 \text { Farm Bill }\end{array}$ & $29.8 \%$ & $22.5 \%$ & $25.4 \%$ & $15.6 \%$ \\
\hline $\begin{array}{l}\text { Farm program commodity payments } \\
\text { should be targeted to small farmers }\end{array}$ & $15.5 \%$ & $13.9 \%$ & $56.1 \%$ & $10.2 \%$ \\
\hline $\begin{array}{l}\text { Existing commodity program payment } \\
\text { limits should be reduced to lower levels }\end{array}$ & $22.5 \%$ & $19.7 \%$ & $34.8 \%$ & $17.2 \%$ \\
\hline $\begin{array}{l}\text { Existing commodity program payment } \\
\text { limits should be changed to apply to a } \\
\text { single individual, eliminating what is } \\
\text { known as the three-entity rule }\end{array}$ & $8.9 \%$ & $15.2 \%$ & $37.7 \%$ & $31.6 \%$ \\
\hline $\begin{array}{l}\text { Existing commodity program payment } \\
\text { limits on marketing loans should be } \\
\text { changed to eliminate the unlimited use of } \\
\text { certificate and forfeiture gains }\end{array}$ & $9.8 \%$ & $16.0 \%$ & $26.6 \%$ & $41.0 \%$ \\
\hline
\end{tabular}

Table 2. Florida producer views on commodity program buy-out.

\begin{tabular}{|lccc|}
\hline \hline Policy Allternative & Yes & No & Don't Know \\
\hline Offer a buy-out & $25.8 \%$ & $33.2 \%$ & $37.3 \%$ \\
15-year buy-out with lump-sum payment & $24.2 \%$ & $24.2 \%$ & $45.1 \%$ \\
15-year buy-out with annual installment payments & $26.6 \%$ & $23.4 \%$ & $46.7 \%$ \\
25 -year buy-out with lump-sum payment & $26.6 \%$ & $20.0 \%$ & $46 / 3 \%$ \\
25-year buy-out with annual installment payments & $25.0 \%$ & $20.5 \%$ & $47.1 \%$ \\
\hline Note: Percentages in tables will not add to 100\% because those who did not answer were not reported. & \\
\hline \hline
\end{tabular}

